\title{
Communication
}

[Comunicação]

\section{Porcine circovirus-2 load in the gastrointestinal tract, mesenteric lymph node, tonsil, and feces of wasted pigs with and without diarrhea}

[Carga viral de circovírus suíno-2 no trato gastrintestinal, linfonodo mesentérico, tonsila e fezes de animais refugo com e sem diarreia]

\section{P. Zlotowski ${ }^{1}$, A.M.R. Corrêa ${ }^{1}$, L.A. Castro $^{1}$, P.K.V. Koerich ${ }^{2}$, D.E.S.N. Barcellos ${ }^{1}$, D. Driemeier ${ }^{1 *}$}

${ }^{1}$ Faculdade de Veterinária - UFRGS

Av. Bento Gonçalves, 9090

91540-000 - Porto Alegre, RS

${ }^{2}$ Perdigão Agroindustrial S.A. - Videira, SC

Porcine circovirus-2 (PCV-2) infection has been associated with a number of syndromes designed as porcine circovirus associated disease (PCVAD) (Opriessnig et al., 2007). PCV-2 was described in enterocytes associated with granulomatous and necrotic enteritis (Jensen et al., 2006). Additionally, PCV-2 was also observed in feces of pigs with and without enteric disease, suggesting that feces are a possible source of virus shedding and the possibility of transmission by the fecal oral route (Yang et al., 2003).

PCV-2 is widespread in swine population, with a high percentage of clinical healthy infected pigs. For that reason, diagnosis of PCVAD in an individual pig is based on the presence of microscopic lesions associated with PCV-2 antigen or nucleic acids by immunohistochemistry (IHC) or in situ hybridization (Opriessnig et al., 2007). RealTime PCR was effective to detect PCV-2 load in feces, allowing the differentiation among subclinical and clinical affected pigs (McIntosh et al., 2008). The objective of this study is to compare PCV-2 DNA load along the gastrointestinal tract, mesenteric lymph node, tonsils, and feces of wasted pigs with and without diarrhea.

This study was performed in three herds (A, B, and $C$ ) in the state of Rio Grande do Sul, Southern Brazil, that had history of diarrhea non responsive to treatment with antibiotic and PCVAD had been previously detected in them. Necropsy was performed in nine wasted animals, one in herd $\mathrm{A}$, six in $\mathrm{B}$, and two in herd $\mathrm{C}$, identified as numbers 1 to 9 . The animals were 108, 70, and 80 day-old, respectively. Fragments from tonsil, stomach (pylorus), duodenum, jejunum, ileum, cecum, colon, rectum, and mesenteric lymph node were collected and fixed for 48 hours in 10\% neutral buffered formalin, processed routinely for histological investigation, and stained with haematoxilyn and eosin. Additionally, fresh fragments from gastrointestinal tract, tonsil, mesenteric lymph node, and feces were collected in sterile centrifuge tube. Real-Time PCR was performed to detect and quantify PCV-2 in fresh and in formalin-fixed, paraffin-embedded tissue sections. IHC anti-PCV-2 was performed in tonsil, duodenum, jejunum, ileum, cecum, colon, stomach, rectum, and mesenteric lymph node using a streptavidin-biotin technique and pretreatment with protease. A rabbit polyclonal antiPCV-2 antiserum was used at a dilution 1:1000 (Sorden et al., 1999). IHC results were grouped according to the intensity of staining: no stained cells (-), slight $(+)$, moderate $(++)$, and accentuated (+++) (Chiannini et al., 2003).

Fresh and paraffin-embedded tissues sections were splited into small pieces and homogenized in phosphate buffered saline (PBS). Nucleic acids were extracted according to the protocol

Recebido em 10 de dezembro de 2009

Aceito em 29 de outubro de 2010

*Autor para correspondência (corresponding author)

E-mail: davetpat@ufrgs.br 
developed by Boom et al. (1990). Real-Time PCR was performed using an Applied Biosystems 7500 Real-Time PCR System with the following program: 3 minutes at $95^{\circ} \mathrm{C}, 45$ cycles of 15 seconds at $95^{\circ} \mathrm{C}$, and 1 minute at $60^{\circ} \mathrm{C}$. PCR amplifications were carried out in $1 \mathrm{X}$ PCR buffer with 5-carboxy-X-rhodamine [ROX] as passive reference dye; $10 \mathrm{mM}$ Tris $\mathrm{HCl}[\mathrm{pH}$ 8.5]; $50 \mathrm{mM} \mathrm{KCl} ; 1.5 \mathrm{mM} \mathrm{MgCl} 2 ; 0.0625 \mathrm{mM}$ each deoxynucleoside triphosphate; $0.5 \mu \mathrm{M}$ primers; $0,125 \mu \mathrm{M}$ probe; $1,6 \mathrm{U}$ of thermostable DNA polymerase (Taq DNA polymerase, Cbiot/Brazil), and $2 \mu \mathrm{L}$ of DNA template, in a final volume of $30 \mu \mathrm{L}$. The primers and probe were the same described by Olvera et al. (2004).

Diarrhea was observed in five animals (numbers $1,2,4,8$, and 9) with aqueous rectal content and presence of pasty feces in perineal area. The main findings in the gastro intestinal tract were enlargement of mesenteric lymph nodes (6/9), intestinal mucosal congestion (4/9), and gastric ulcer in the aglandular zone of the stomach (3/9). Paleness in the oral and ocular mucosal surface and pasty feces with blood, extensive gastric ulcer in the aglandular zone, and blood clot covering the ulceration were observed in animal number 1. Gastric ulcer was also observed in animals numbers 8 and 9 . Animal number 9 had also dry feces adhered in colonic mucosal surface. Pleural adherence in the lung and cyphosis were additional findings in pigs numbers 3 and 6 , respectively.

Microscopically, lymphohistiocytic infiltrate was observed in the mucosa of small (8/9) and large intestine (5/9) and in mesenteric lymph node (9/9) in variable amounts. In small intestines, Peyer patches depletion (5/9), giant cells (2/9), and mucosal lymphatic vessel dilatation (2/9) were also observed. In the colon of animal number 9 , multifocal areas of erosion of the mucosa with cryptal necrosis and dilatation with necrotic debris in the cryptal lumen were observed. Moderated to discrete lymphoid depletion and lymphohistiocytic infiltrate were observed in tonsils (6/9).

PCV-2 IHC was positive in five of the nine pigs analyzed, grouped as PCV-2 affected pigs. Diarrhea was observed in all animals from the PCV-2 affected group. The intensity of staining in the tissues is detailed in Table 1.
PCV-2 DNA was detected in all tested samples, which presented a wide range of viral loads (Figure 1). The highest viral loads were observed in tissues and feces from animals with diarrhea, being higher than $10^{7}$ copies per 500ng of DNA. A threshold of $10^{7} \mathrm{PCV}-2$ genome copies per 500ng of DNA has been considered diagnostic for the presence of PCVAD (Olvera et al., 2004). In accordance with the literature, animals presenting clinical signs had higher viral loads than infect animals without clinical signs.

Data were assessed by analysis of variance using SPSS 16.0 (SPSS Inc.). Differences were considered significant for all test procedures when $\mathrm{P}>0.05$ or 0.01 . Differences between groups were evaluated with Tukey's test. Viral load correlation between fresh tissues and paraffin-embedded was evaluated by nonparametric correlations test, Spearman's Rho in Multivariete Methods using SPSS, showing similar values between them with $r=0,84$, $\mathrm{P}<0.0001$.

Enterocytes are periodically renewed in pigs older than three weeks, in which the migration of immature cells to the top of the villous, as mature cells, takes two to four days (Cook et al., 1996). As this process occurs, the dead cells, replaced for this renewed cells, are desquamated along the intestinal tract. PCV-2 infected enterocytes desquamated during intestinal renew and the presence of those enterocytes in feces may be responsible for the higher viral load in feces of PCV-2 affected pigs, increasing viral shed in PCV-2 affected herd, making the fecal-oral an important route of infection in those herds.

Mesenteric lymph nodes from pigs with diarrhea were the tissues that showed the highest viral concentration compared with those that did not have diarrhea. It is believed that PCV-2 replication begins in lymph nodes nearest to the site of infection and those lymph nodes may play an important role in viral persistence in infected host. Similar results were observed in pigs with inoculation of PCV-2 by the intranasal route with the highest viral DNA load observed in bronchial lymph node, the closest lymphoid tissue of the inoculation site ( $\mathrm{Yu}$ et al., 2007). The present findings suggest that mesenteric lymph node may be a site for viral persistency in PCV-2 affected pigs showing diarrhea. 


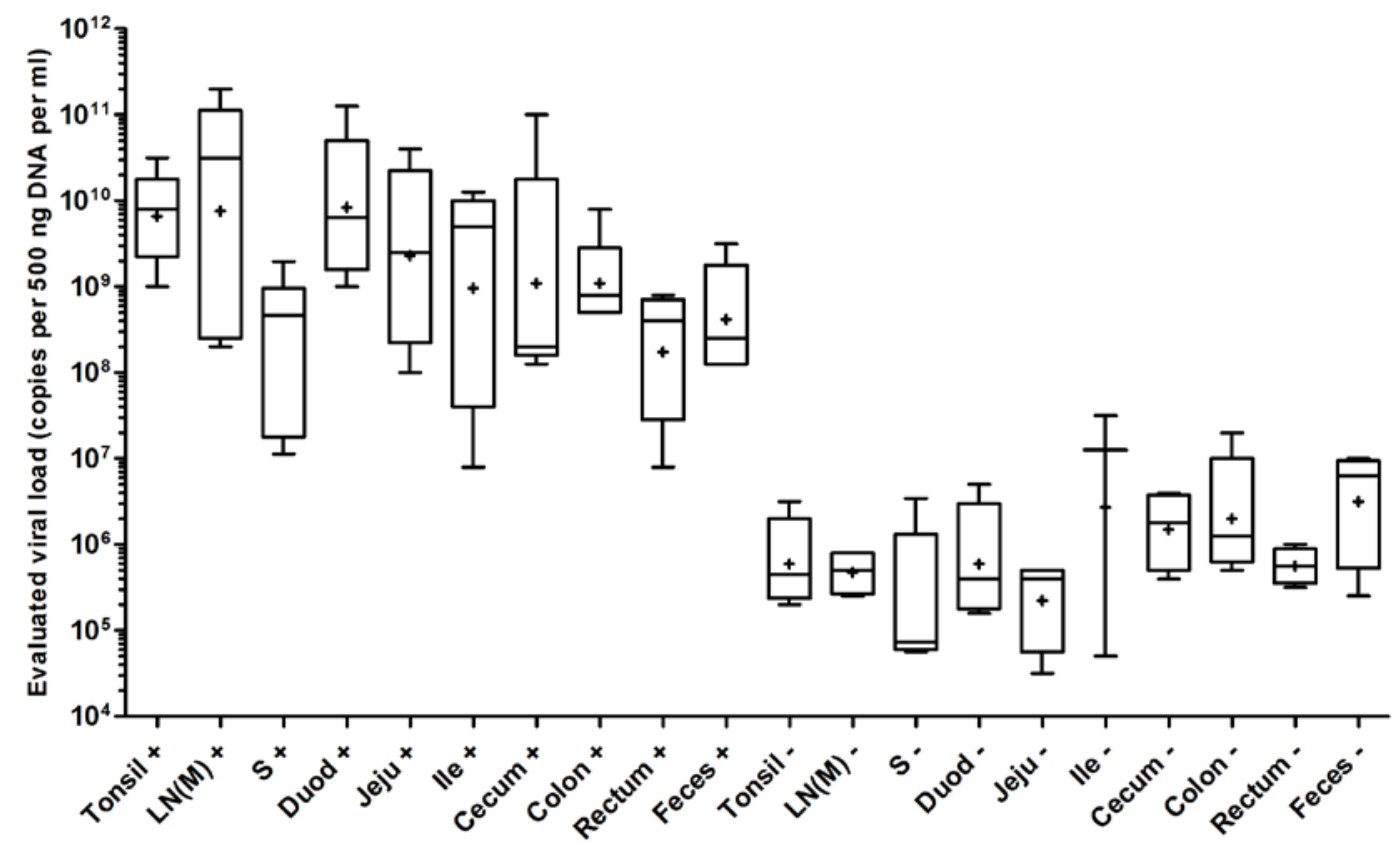

Figure 1. Box plot of estimated PCV-2 viral load (copies per 500 ng DNA) from several organs of IHQ positive $(+)$ and negative $(-)$ animals $(N=9)$. The horizontal lines in the box denote the 25th, 50th, and 75th percentile values. The error bars denote the 5th and 95th percentile values. The cross symbol denotes the mean of the column. Some of the symbols denoting different percentiles coincide due to low numbers of observations within each group. LN(M) mesenteric lymph node; (S) stomach (pylorus); (Duod) duodenum; (Jeju) jejunum; (Ile) ileum.

The infectivity capacity of PCV-2 detected in feces was not tested; however, the quantitative values of PCV-2 in feces were associated with the values in tissues of the gastrointestinal tract in PCV-2 affected pigs. Virus titration in different tissues was previously correlated with clinical situation (Allan et al., 1999), making possible the suggestion that the virus present in the feces of those PCV-2 affected pigs had infectivity capacity. Similar results were observed with rectal swabs by Segalés et al. (2005).

Retrospective studies were conducted to provide a better understanding of PCV-2 infection and epidemiology in herds worldwide (RodríguezArrioja et al., 2003; Jacobsen et al., 2009). These studies are performed mainly with samples fixed in formalin and stored in paraffin-embedded blocks from laboratories of veterinary investigation using immunohistochemical and molecular biology techniques (Jacobsen et al., 2009). However, it is reported that formalin fixation may interfere in PCR technique (Kim et al., 2003), making difficult the identification of PCV-2 in samples. The present findings, using Real-Time PCR, indicated that fresh and paraffin-embedded samples had similar results in the viral load of PCV-2 in samples from the gastrointestinal tract, tonsils, and mesenteric lymph node. Real-Time PCR in paraffinembedded samples may be a useful tool in the studies of PCV-2 epidemiology, allowing the quantification of the viral load in storage samples in times before the emergency of postweaning multisystemic wasting syndrome (PMWS in herds worldwide, comparing these results with actual findings. Additional studies are required to compare viral load in fresh and paraffinembedded samples from PCV-2 affected pigs. 
Table 1. PCV-2 immunohistochemistry staining intensity in different tissues and gross lesions in wasted pigs

\begin{tabular}{lccccccccc} 
& Pig 1 & Pig 2 & Pig 3 & Pig 4 & Pig 5 & Pig 6 & Pig 7 & Pig 8 & Pig 9 \\
\hline Tonsil & +++ & ++ & - & ++ & - & - & - & +++ & +++ \\
Duodenum & +++ & + & - & ++ & - & - & - & ++ & +++ \\
Jejunum & + & +++ & - & ++ & - & - & - & +++ & +++ \\
Ileum & ++ & ++ & - & + & - & - & - & +++ & +++ \\
Cecum & - & - & - & - & - & - & - & ++ & +++ \\
Colon & ++ & + & - & + & - & - & - & ++ & +++ \\
Rectum & - & ++ & - & - & - & - & - & + & - \\
LN (M) & +++ & +++ & - & ++ & - & - & - & +++ & +++ \\
Stomach & ++ & + & - & - & - & - & - & + & +++ \\
Gross lesions & & & & & & & & & no \\
Diarrhea & yes & yes & no & yes & no & no & no & yes \\
Gastric Ulcer & yes & no & no & no & no & no & no & yes & yes
\end{tabular}

(-) no stained cells, (+) slight, (++), moderate, and (+++) accentuated. LN (M) mesenteric lymph node

Keywords: PCV-2, viral load, diarrhea

\section{RESUMO}

Relata-se a quantificação de PCV-2, por meio de PCR em tempo real, no trato gastrintestinal, linfonodo mesentérico, tonsilas e fezes de nove suínos refugo da fase de crescimento, provenientes de rebanhos com histórico de diarreia não responsiva ao tratamento com antibioticoterapia. Com base nos resultados histopatológicos e imunoistoquímicos, os animais foram classificados como afetados por PCV-2 $(n=5) e$ não afetados $(n=4)$. Foi observada diarreia em todos os animais do grupo afetado por PCV-2. Em todas as amostras testadas foi detectado PCV-2, no entanto, a carga viral observada nos tecidos, bem como a excreção nas fezes foi significantemente maior $(P \leq 0.01)$ nos animais com diarreia. A maior concentração de PCV-2 foi observada nos linfonodos mesentéricos. A carga viral observada em tecido fresco e nas mesmas amostras emblocadas em parafina foi semelhante, sugerindo que o PCR em tempo real pode ser uma ferramenta útil em estudos retrospectivos da infecção por PCV-2.

Palavras-chave: PCV-2, carga viral, diarreia

\section{ACKNOWLEDGEMENTS}

This work was supported with scholarship given by the CAPES and research grants given the CNPq.

\section{REFERENCES}

ALLAN, G.M.; KENNEDY, S.; MCNEILLY, F. et al. Experimental reproduction of severe wasting disease by co-infection of pigs with porcine circovirus and porcine parvovirus. J. Comp. Pathol., v.121, p.1-11, 1999.

BOOM, R.; SOL, C.J.; SALIMANS, M.M. et al. Rapid and simple method for purification of nucleic acids. J. Clin. Microbiol., v.28, p.495-503, 1990.
CHIANINI, F.; MAJO, N.; SEGALÉS, J. et al. Immunohistochemical characterization of PCV-2 associated lesions in lymphoid and non-lymphoid tissues of pigs with natural postweaning multisystemic wasting syndrome (PMWS). Vet. Immunol. Immunopathol., v.94, p.63-75, 2003.

COOK, R.W. Small Intestine. In: SIMS, L.D.; GLASTONBURY, J.R.W. (Ed.). Pathology of the pig: a diagnostic guide. Barton: The pig Research and Development Corporation, 1996. p.57-88.

JACOBSEN, B.; KRUEGER, L.; SEELIGER, F. et al. Retrospective study on the occurrence of porcine circovirus 2 infection and associated entities in Northern Germany. Vet. Microbiol., v.138, p.27-33, 2009. 
JENSEN, T.K.; VIGRE, H.; SVENSMARK, B. et al. Distinction between porcine circovirus type 2 enteritis and porcine proliferative enteropathy caused by Lawsonia intracellularis. J. Comp. Pathol., v.135, p.176-182, 2006.

KIM, J.; CHAE, C. Multiplex nested PCR compared with in situ hybridization for the differentiation of porcine circoviruses and porcine parvovirus from pigs with postweaning multisystemic wasting syndrome. Can. J. Vet. Res., v.67, p.133-137, 2003.

McINTOSH, K.A.; HARDING, J.C.S.; PARKER, S. et al. Quantitative polymerase chain reaction for porcine circovirus- 2 in swine feces in a porcine circovirus disease-affected commercial herd and a non-affected commercial herd. Can. Vet. J., v.49, p.1189-1194, 2008.

OLVERA, A.; SIBILA, M.; CALSAMIGLIA, M. et al. Comparison of porcine circovirus type 2 in serum quantified by a real time PCR in postweaning multisystemic wasting syndrome and porcine dermatitis and nephropathy syndrome naturally affected pigs. J. Virol. Methods, v.1117, p.75-80, 2004.

OPRIESSNIG, T.; MENG, X-J.; HALBUR, P.G. Porcine circovirus type-2 associated disease: update on current terminology, clinical manifestations, pathogenesis, diagnosis, and intervention strategies. J. Vet. Diagn. Invest., v.19, p.591-615, 2007.
RODRÍGUEZ-ARRIOJA, G.M.; SEGALÉS, J.; ROSELL, C. et al. Retrospective study on porcine circovirus type 2 infection in pigs from 1985 to 1997 in Spain. J. Vet. Med. B, v.50, p.99-101, 2003.

SEGALÉS, J.; CALSAMIGLIA, M.; OLVERA, A. et al. Quantification of porcine circovirus type 2 (PCV-2) DNA in serum and tonsilar, nasal, tracheobronchial, urinary and faecal swabs of pigs with and without postweaning multisystemic wasting syndrome (PMWS). Vet. Microbiol., v.111, p.223229, 2005.

SORDEN, S.D.; HARMS, P.A.; NAWAGITGUL, $P$. et al. Development of a polyclonal-antibodybased immunohistochemical method for the detection of type 2 porcine circovirus in formalinfixed, paraffin-embedded tissue. J. Vet. Diag. Invest., v.11, p.528-530, 1999.

YANG, J.S.; SONG, D.S.; KIM, S.Y. et al. Detection of porcine circovirus type 2 in feces of pigs with or without enteric disease by polymerase chain reaction. J. Vet. Diagn. Invest., v.15, p.69-73, 2003.

YU, S; OPRIESSNIG, T; KITIKOON, P. et al. Porcine circovirus type 2 (PCV-2) distribution and replication in tissues and immune cells in early infected pigs. Vet. Immunol. Immunopathol., v.115, p.261-272, 2007. 